\title{
ADULTICIDAL ACTIVITY AGAINST Stegomyia aegypti (DIPTERA: CULICIDAE) OF THREE Piper spp.
}

\author{
Wej CHOOCHOTE, Udom CHAITHONG, Kittichai KAMSUK, Eumporn RATTANACHANPICHAI, Atchariya JITPAKDI, Pongsri TIPPAWANGKOSOL, \\ Dana CHAIYASIT, Daruna CHAMPAKAEW, Benjawan TUETUN \& Benjawan PITASAWAT
}

\begin{abstract}
SUMMARY
Three Piper species, Piper longum, P. ribesoides and P. sarmentosum, were selected for investigation of adulticidal potential against Stegomyia aegypti, a main vector of dengue and dengue haemorrhagic fever. Successive extraction by maceration with $95 \%$ ethanol showed percentage yields of ethanolic extracts, which derived from P. longum, P. ribesoides and P. sarmentosum, of 8.89, 3.21 and 5.30\% (w/w), respectively. All Piper extracts illustrated an impressive adulticidal activity when tested against female mosquitoes by topical application. The susceptibility of St. aegypti females to ethanol-extracted Piper was dose dependent and varied among the plant species. The highest adulticidal effect was established from $P$. sarmentosum, followed by $P$. ribesoides and $P$. longum, with $\mathrm{LD}_{50}$ values of $0.14,0.15$ and $0.26 \mu \mathrm{g} / \mathrm{female}$, respectively. The potential of these Piper species, as possible mosquitocides, established convincing activity for further researches to develop natural substances for combat against adult mosquitoes.
\end{abstract}

KEYWORDS: Piper; Piper longum; Piper ribesoides; Piper sarmentosum; Stegomyia aegypti; Adulticidal activity; Topical application.

\section{INTRODUCTION}

Stegomyia aegypti (redirected from Aedes aegypti) ${ }^{18}$ mosquitoes are the primary carrier of dengue and dengue haemorrhagic fever in many developing countries in the tropical world ${ }^{33}$. In Thailand, annual dengue incidences are quite high and have been increasing and spreading recently to newer areas ${ }^{10}$. Like the case of malaria, a vaccine for dengue and dengue haemorrhagic fever is not yet available. Consequently, a reliable way to diminish the incidence of these diseases is to eradicate the mosquito vectors through continued applications of synthetic insecticides. However, the problems of high cost, toxic hazards to humans and other non-target creatures, and development of resistance to conventional insecticides in many mosquito species have revived great interest in exploiting the vector control potential of natural origins. Research and the development of mosquito control alternatives have focused on plant-derived constituents or phytochemicals s,27,30,34. $^{2}$.

Botanical insecticides may serve as suitable alternatives to synthetics in future, as they are relatively safe, degradable and readily available in many parts of the world ${ }^{24}$. Recently, plants in the family, Piperaceae, have been of interest because they contain insecticidal principles $^{2,9}$. Little work has been carried out on mosquito adulticidal activity, although some Piper spp. and their bioactive constituents are reported to have noteworthy larvicidal potential against various species of mosquitoes such as Culex pipiens pallens, Aedes aegypti, Ae. togoi and Ae. atropalpus ${ }^{8,13,14}$. In a search for effective and affordable natural substances for use in the control of mosquito-borne diseases, three Piper spp. available in Thailand including Piper longum, P. ribesoides and $P$. sarmentosum were chosen to evaluate their adulticidal potential against the St. aegypti mosquito.

The Piperaceae family contains approximately 2,000 species, which are widely distributed and commonly used in tropical and subtropical regions as food, spice, traditional medicines and pest control agents $^{11,12,21}$. P. longum, $P$. ribesoides and $P$. sarmentosum, widely grown throughout Thailand, have been locally known as De-plee, Ta-khaan and Cha-plu, respectively. These Piper species have been traditionally used in Thailand for food and medicinal purposes ${ }^{16,19}$. P. longum is reported as good remedy used for treatment of gonorrhea, menstrual pain, tuberculosis, sleeping problems, respiratory tract infections, chronic gut related pain and arthritic conditions ${ }^{22}$. Additionally, analgesic and diuretic effects, relaxation of muscle tension and alleviation of anxiety have also been reported ${ }^{23} . P$. ribesoides and $P$. sarmentosum are commonly used in folk medicine as a carminative. $P$. sarmentosum has also been used as an expectorant, and to relieve muscle pain $^{16,19}$. Methanol extracts of $P$. longum fruit and $P$. sarmentosum root have been proved to possess the anti-amoebic effects against Entamoeba histolytica infecting the caecum of mice ${ }^{20} . P$. longum and its component piperine have accounted as a non-toxic immunomodulator which possess antitumor property also ${ }^{28}$. The water extract of whole plant of 


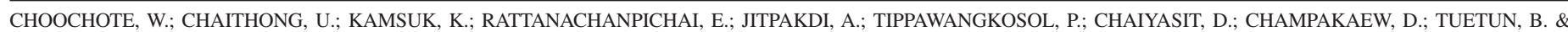
PITASAWAT, B. - Adulticidal activity against Stegomyia aegypti (Diptera: Culicidae) of three Piper spp. Rev. Inst. Med. trop. S. Paulo, 48(1): 33-37, 2006.

$P$. sarmentosum has been noted for a hypoglycemic effect in rats ${ }^{15}$. Brachyamide B and 3',4',5'-trimethoxycinnamoyl pyrrolidine, bioactive compounds derived from $P$. sarmentosum fruits, have been reported to exert antituberculosis activity and antiplasmodial potential against Plasmodium falciparum parasite ${ }^{17}$.

\section{MATERIALS AND METHODS}

Plant preparation and extraction: Three Piper species of the Piperaceae family, Piper longum Linn., Piper ribesoides Wall. and Piper sarmentosum Roxb. were obtained from E.A.R. Samunpri, a traditional herb supplier in Chiang Mai province, Thailand. Taxonomic identification of plants was performed by J.F. Maxwell, botanists at the CMU Herbarium, Department of Biology, Faculty of Science, Chiang Mai University, Thailand. The voucher specimens (PARA-PI001/1, PARA-PI-002/1, and PARA-PI-003/1, respectively) were preserved at the Department of Parasitology, Faculty of Medicine, Chiang Mai University. Dried material of each plant (1 kg) was crushed and successively extracted three times by maceration, with $3 \mathrm{~L}$ of $95 \%$ ethanol at room temperature for seven days. The ethanolic extracts were separated by suction filtered through a Büchner funnel. Solvent in combined filtrates was removed by rotary evaporator at temperatures below $60{ }^{\circ} \mathrm{C}$ until the extract was rather concentrated. The resulting crude extracts were transferred to an open container set on a hot plate and the residual solvent was removed for at least 24 hours. The ethanolic extract of each plant was thus obtained, lyophilized and then refrigerated at $-20{ }^{\circ} \mathrm{C}$ until testing for adulticidal activity.

Test mosquitoes: Laboratory colonies of Stegomyia aegypti, which originated from larvae collected at various places in Chiang Mai province, northern Thailand, had been reared continuously for several generations in a laboratory free of exposure to pathogens and insecticides. They were maintained at $25-30{ }^{\circ} \mathrm{C}$ and $80-90 \%$ relative humidity under a photoperiod of 14:10 h (light/dark) in the insectarium of the Department of Parasitology, Faculty of Medicine, Chiang Mai University, Chiang Mai province. Larvae were fed on a ground commercial dog biscuit. The adults were reared in humidified cages and supplied with $10 \%$ sucrose and $10 \%$ multivitamin syrup. Female mosquitoes were periodically blood-fed on restrained rats to obtain protein used principally for egg production. Under these conditions, the full development from egg to adult lasted about 3-4 weeks. Batches of 2-5 day-old healthy female mosquitoes were used in the adulticidal bioassay.

Adulticidal bioassay: The adulticidal activity of the Piper extracts was determined by topical application of the insecticide to the adult female mosquitoes (Fig. 1), following slightly modified versions of the WHO standard protocols ${ }^{32}$. Each plant extract was dissolved in acetone yielding a graded series of concentrations. Non-blood fed females were briefly anaesthetized with carbon dioxide $\left(\mathrm{CO}_{2}\right)$, weighed and placed on a cold plate. Treatment was performed with the aid of a dissecting microscope. A $0.1 \mu \mathrm{L}$ droplet of plant solution in acetone was applied onto the upper part of the immobilized mosquito's pronotum using a Hamilton's digital syringe (700 series MICROLITER ${ }^{\mathrm{TM}}$, Hamilton Company, USA). Dosages were expressed in the $\mu \mathrm{g}$ of plant material per mg of mosquito body weight. A total of 25 individuals was used at each concentration, with 4-6 concentrations providing a range of $0-100 \%$ mortality. Controls were divided into

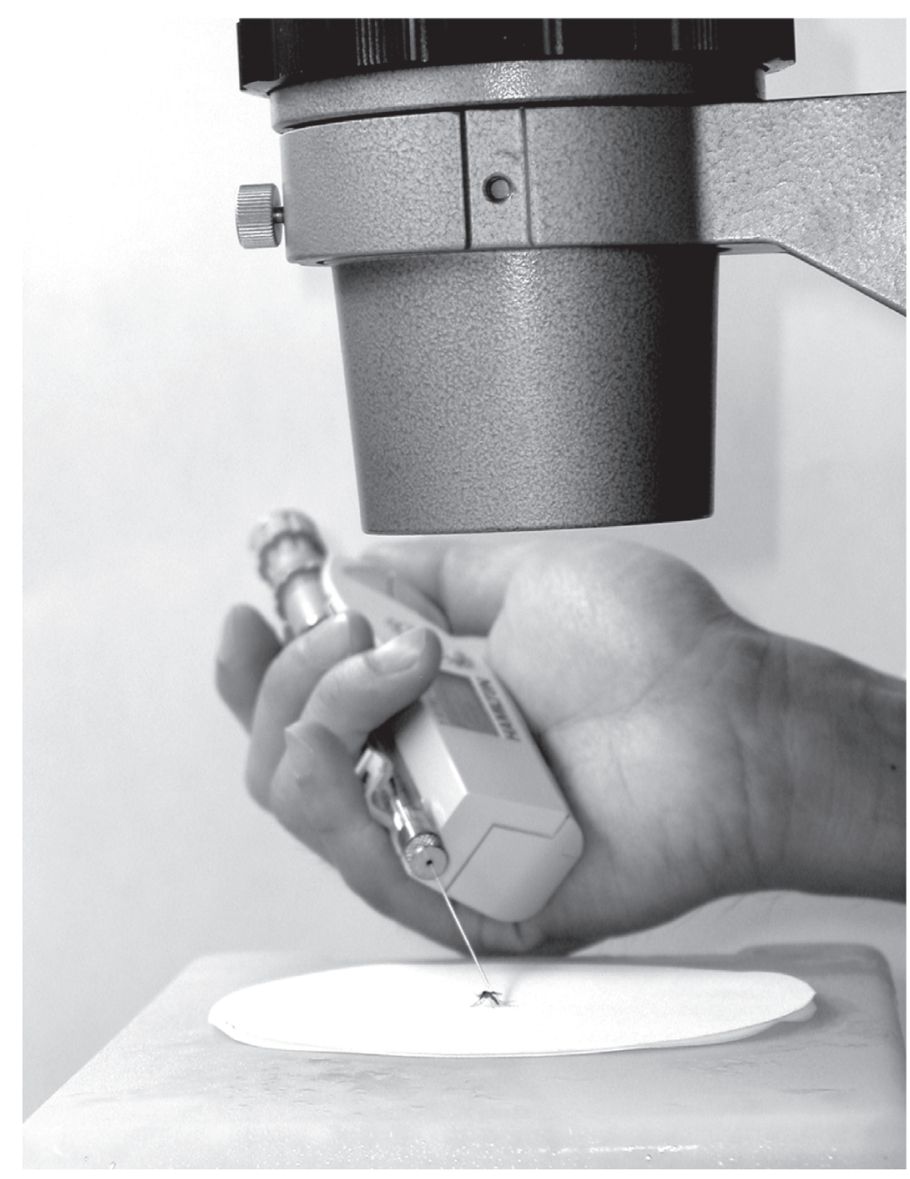

Fig. 1 - Topical application of the Piper extracts to St. aegypti female mosquitoes with the aid of a dissecting microscope.

two groups including acetone treated and untreated groups. Both groups were treated in a similar manner to that of Piper treated groups. After application, the females in all groups were maintained at $27 \pm 3{ }^{\circ} \mathrm{C}$ and $80 \% \pm 10 \% \mathrm{RH}$ in plastic cups, with $10 \%$ sucrose and $10 \%$ multivitamin syrup provided. At the end of a 24-hour recovery period, the mosquitoes were considered dead if they showed no sign of movement such as lying on the bottom of the plastic cup and not responding to mechanical stimulation. Eight replicates were carried out for each plant extract with mosquitoes from different rearing batches, and the results were pooled.

Data management and statistical analysis: It was essential to obtain not less than three mortality counts of between $10 \%$ and $90 \%$. Experimental tests that demonstrated more than $20 \%$ control mortality were discarded and repeated. However when the control mortality ranged from $5-20 \%$, the observed percentage mortality $(\% \mathrm{M})$ was corrected by Abbott's formula':

$$
\% \mathrm{M}=\frac{\% \text { test mortality }-\% \text { control mortality }}{100-\% \text { control mortality }} \times 100
$$

The $95 \%$ confidence intervals (CI) of the lethal dosage of $50 \%$ and $95 \%\left(\mathrm{LD}_{50}\right.$ and $\mathrm{LD}_{95}$, respectively) calculated by a computerized 
log-probit analysis (Harvard Programming; $\mathrm{Hg} 1,2$ ) were used to measure differences between test samples.

\section{RESULTS}

Successive extraction by maceration with $95 \%$ ethanol showed the percentage yield of ethanolic extracts, which derived from $P$. longum, $P$. ribesoides and $P$. sarmentosum in relation to the starting dry material that averaged 8.89, 3.21 and 5.30\% (w/w), respectively. These alcoholic extracts showed various strengths of odor and a high solubility in absolute ethanol, DMSO or acetone (Table 1). Investigating against female St. aegypti by topical application in this study revealed a pronounced toxic effect in all Piper extracts (Table 2). The susceptibility of St. aegypti females to a graded series of concentrations of each ethanol-extracted Piper was dose dependent. Following treatment with increasing concentrations of $P$. longum, $P$. ribesoides and $P$. sarmentosum from $0.10-0.50,0.025-0.40$ and $0.05-0.30 \mu \mathrm{g} / \mathrm{mg}$ female, respectively, the mortality values increased from 6.5-84.5, 6.0-97.5 and 3.0-89.5\%, respectively. Comparison of adulticidal activity of these ethanolicextracted peppers demonstrated that the highest potential was established from $P$. sarmentosum, followed by $P$. ribesoides and $P$. longum with $\mathrm{LD}_{50}$ values of $0.14,0.15$ and $0.26 \mu \mathrm{g} / \mathrm{mg}$ female, respectively. Although $P$. sarmentosum provided slightly better activity than $P$. ribesoides, no statistically significant difference was found, based on the overlapping of $95 \%$ confidence interval at $\mathrm{LD}_{50}$ values. No mortality was detected in any acetone treated or untreated groups.

Table 1

Botanical data, physical characters, solubility and percentage yields of ethanolic extracts of Piper spp.

\begin{tabular}{|c|c|c|c|c|c|c|c|}
\hline \multirow[t]{2}{*}{ Botanical name } & \multirow[t]{2}{*}{ Common name } & \multirow[t]{2}{*}{ Part used } & \multicolumn{3}{|c|}{ Physical character } & \multirow[t]{2}{*}{ Solubility } & \multirow[t]{2}{*}{ Yield $(\%)$} \\
\hline & & & Appearance & Color & $\overline{\text { Odor }}$ & & \\
\hline P. longum & Javanese long pepper & & Semi-solid & Dark brou & Sweet-spi & Soluble in eth & 8.89 \\
\hline P. ribesoides & Jakhang pepper & Wood & Semi-solid & Dark brown & Raw smell & Soluble in DMSO \& acetone & 3.21 \\
\hline P. sarmentosum & Yariegatum & Whole plant & Semi-solid & Dark green & Sweet-herbal & Soluble in DMSO \& acetone & 5.30 \\
\hline
\end{tabular}

Table 2

Adulticidal activity of the ethanolic extracts derived from three Piper species against adult female St. aegypti

\begin{tabular}{|c|c|c|c|c|}
\hline \multirow[t]{2}{*}{$\begin{array}{l}\text { Piper species extract } \\
(\mu \mathrm{g} / \mathrm{mg} \text { female })\end{array}$} & \multirow[t]{2}{*}{$\begin{array}{l}\% \text { Mortality } \\
(\text { Mean } \pm \text { SE) }\end{array}$} & \multicolumn{3}{|c|}{$\begin{array}{c}\text { Adulticidal activity } \\
\text { (95\% C.I., } \mu \mathrm{g} / \mathrm{mg} \text { female) }\end{array}$} \\
\hline & & $\mathrm{LD}_{50}$ & $\mathrm{LD}_{95}$ & $\mathrm{LD}_{99}$ \\
\hline $\begin{array}{l}\text { P. longum } \\
0.10 \\
0.20 \\
0.30 \\
0.40 \\
0.50 \\
\text { Control } \\
\text { Untreated }\end{array}$ & $\begin{array}{c}6.5 \pm 1.41 \\
30.5 \pm 3.15 \\
65.5 \pm 3.25 \\
79.5 \pm 2.03 \\
84.5 \pm 2.42 \\
0 \\
0\end{array}$ & $\begin{array}{c}0.26 \\
(0.23-0.28)\end{array}$ & $\begin{array}{c}0.71 \\
(0.60-0.95)\end{array}$ & $\begin{array}{c}1.27 \\
(0.95-2.02)\end{array}$ \\
\hline $\begin{array}{l}\text { P. ribesoides } \\
0.025 \\
0.05 \\
0.10 \\
0.20 \\
0.30 \\
0.40 \\
\text { Control } \\
\text { Untreated }\end{array}$ & $\begin{array}{c}6 \pm 1.77 \\
15.5 \pm 2.42 \\
29.5 \pm 2.77 \\
62.5 \pm 4.40 \\
78 \pm 2.67 \\
97.5 \pm 1.06 \\
0 \\
0\end{array}$ & $\begin{array}{c}0.15 \\
(0.13-0.17)\end{array}$ & $\begin{array}{c}0.83 \\
(0.60-1.38)\end{array}$ & $\begin{array}{c}2.17 \\
(1.32-4.65)\end{array}$ \\
\hline $\begin{array}{l}\text { P. sarmentosum } \\
0.05 \\
0.10 \\
0.20 \\
0.30 \\
\text { Acetone } \\
\text { Untreated }\end{array}$ & $\begin{array}{c}3 \pm 0.89 \\
30.5 \pm 1.77 \\
71 \pm 3.57 \\
89.5 \pm 0.74 \\
0 \\
0\end{array}$ & $\begin{array}{c}0.14 \\
(0.12-0.15)\end{array}$ & $\begin{array}{c}0.42 \\
(0.34-0.58)\end{array}$ & $\begin{array}{c}0.79 \\
(0.57-1.32)\end{array}$ \\
\hline
\end{tabular}


CHOOCHOTE, W.; CHAITHONG, U.; KAMSUK, K.; RATTANACHANPICHAI, E.; JITPAKDI, A.; TIPPAWANGKOSOL, P.; CHAIYASIT, D.; CHAMPAKAEW, D.; TUETUN, B. \& PITASAWAT, B. - Adulticidal activity against Stegomyia aegypti (Diptera: Culicidae) of three Piper spp. Rev. Inst. Med. trop. S. Paulo, 48(1): 33-37, 2006.

\section{DISCUSSION}

Piperaceae plants are widely used in tropical and subtropical regions throughout the world as medicines, spice, food flavoring and pest control substances ${ }^{21,25}$. Recently, there has been a growing interest in plants belonging to the family, Piperaceae, as potential sources of bioactive chemical compounds against insect pests. While excellent effects on mosquito vectors from larvicidal constituents that derived from some Piper species have been reported ${ }^{8,13,14,35}$, little work has been carried out on Piper toxicity against adult mosquitoes. The potential of three Piper species, $P$. longum, $P$. ribesoides and $P$. sarmentosum against St. aegypti, as observed at 24 hours following treatment in this investigation, was strong and found to have various degrees of adulticides. St. aegypti adults were most susceptible to $P$. sarmentosum followed by $P$. ribesoides and P. longum $\left(\mathrm{LD}_{50}: 0.14\right.$, 0.15 and $0.26 \mu \mathrm{g} / \mathrm{mg}$ female, respectively). However, the adulticidal activity of the two former species, $P$. sarmentosum and $P$. ribesoides, showed no statistically significant difference, and was considered to be approximately equal, and higher than that of $P$. longum. The variety in adulticidal activity of these extracts is probably due to variation in the types and levels of active ingredients that depend on not only the genetic characteristics of the plant species, but also the conditions under which they were grown and harvested ${ }^{29,31}$.

The literature offers no publication on the toxicity of natural plant products against adult St. aegypti or other mosquito species, measured by topical application. KHAN \& $\mathrm{AHMED}^{7}$ revealed the toxicity of crude neem leaf extract against the adult of housefly Musca domestica, investigated by topical application, with $\mathrm{LD}_{50}$ and $\mathrm{LD}_{95}$ values of 8.4 and $169.8 \mu \mathrm{g} / \mathrm{fly}$, respectively. The $\mathrm{LD}_{50}$ values of male and female $M$. domestica treated with commercial eucalyptol were 118 and $177 \mu \mathrm{g} /$ fly, respectively, whereas those of male and female Chrysomya megacephala were 197 and $221 \mu \mathrm{g} / \mathrm{fly}$, respectively ${ }^{26}$. The St. aegypti mosquito is actually smaller in size and lower in weight $(\approx 10$-fold $)$ than $M$. domestica and $C$. megacephala. With regard to the size and weight of insect and lethal dosage parameter, although insect susceptibility to each plant product generally demonstrates an interspecies variability, it could be expected that the toxic effect of Piper products was greater than that of eucalyptol and neem, the popular plant-based insecticide. The adulticidal potential of $P$. ribesoides, $P$. sarmentosum and $P$. longum investigated in this study is encouraging, but not as much as that of conventional synthetic insecticides. CORBEL et $a l .{ }^{5}$ reported the excellent intrinsic toxicity of some chemical insecticides measured by topical application against many mosquito species. The $\mathrm{LD}_{50}$ of bifenthrin, permethrin and temephos were 0.077 , 0.24 and $195 \mathrm{ng} / \mathrm{mg}$ female, respectively, when tested against $A e$. aegypti adults. The adulticidal activity of the Piper spp. seemed much less toxic against female St. aegypti (Ae. aegypti) than these commonly used insecticides by more than 10 -fold at the $\mathrm{LD}_{50}$ level. Pyrethroids and organophosphates resistance, however, is now widely developed in mosquitoes of medical importance . $^{5}$.

Aerial toxicants are partially effective in eradicating Ae. aegypti, which are highly domesticated, and many adults hide indoors ${ }^{4}$. Insecticide space-spraying against adult mosquitoes is still necessary during epidemics of dengue. However, the use of aerosolized pyrethroid insecticides in public health programs can cause allergies in the human population $^{3}$. There have also been questions raised regarding the long- term persistence and other possible hazards to human health from conventional applications. The results from this research are encouraging and clearly demonstrate the potential of these Piper species as possible mosquitocides against St aegypti. The pepper plants, $P$. longum, $P$. ribesoides and $P$. sarmentosum may be used as alternatives for managing adult flying mosquitoes. Further work on Piper-derived constituents is needed to develop effective formulations for controlling adult mosquitoes. Moreover, further research to identify the biologically active compounds in Piper extracts, which showed potent adulticidal activity, is already in progress.

\section{RESUMO}

\section{Atividade de três Piper spp. contra adultos de Stegomyia aegypti (Diptera: Culicidae)}

Três espécies de Piper, Piper longum, $P$. ribesoides e $P$. sarmentosum, foram selecionadas para investigação da potencialidade contra Stegomyia aegypti adultos, principal vetor de dengue e febre do dengue hemorrágico. Sucessivas extrações por maceração com etanol a $95 \%$ mostraram uma porcentagem de extratos etanólicos, derivados de $P$. longum, $P$. ribesoides e $P$. sarmentosum, de 8,89, 3,21 e 5,30\% (w/w), respectivamente. Todos os extratos de Piper mostraram atividade adulticida expressiva quando testados contra fêmeas de mosquitos através de aplicação tópica. A suscetibilidade das fêmeas do St. aegypt ao extrato de Piper etanólico foi dose dependente e variou entre as espécies de plantas. O mais elevado efeito adulticida foi demonstrado a partir do $P$. sarmentosum, seguido pelo $P$. ribesoides e $P$. longum, valores $\mathrm{LD}_{50}$ de $0,14,0,15$ e $0,26 \mu \mathrm{g} /$ fêmea, respectivamente. $\mathrm{O}$ potencial destas espécies de Piper, como possíveis mosquiticidas, estabeleceu atividade convincente para futuras pesquisas a fim de desenvolver substâncias naturais para o combate a mosquitos adultos.

\section{ACKNOWLEDGEMENTS}

The authors acknowledge the staff members of the Department of Parasitology, Faculty of Medicine, Chiang Mai University for their kind cooperation and great assistance in this research project. Acknowledgment is extended to the Faculty of Medicine Endowment Fund for its financial support of this research project and the Faculty of Medicine Endowment Fund for Research Publication for its financial support in publishing this paper.

\section{REFERENCES}

1. ABBOTT, W.S. - A method of computing the effectiveness of an insecticide. J. Econ. Entomol., 18: 265-266, 1925.

2. ASSABGUI, R.; LORENZETTI, F.; TERRADOT, L. et al. - Efficacy of botanicals from the Meliaceae and Piperaceae. In: HEDIN, P.A.; HOLLINGWORTH, R.M.; MASLER, E.P.; MIYAMOTO, J. \& THOMPSON, D.G., ed. Phytochemicals for pest control. Washington, American Chemical Society, 1997. p. 38-48. (ACS Symposium Series 658).

3. CAVALCANTI, E.S.B.; DE MORAIS, S.M.; LIMA, M.A.A. et al. - Larvicidal activity of essential oils from Brazilian plants against Aedes aegypti L. Mem. Inst. Oswaldo Cruz., 99: 541-544, 2004.

4. CICCIA, G.; COUSSIO, J. \& MONGELLI, E. - Insecticidal activity against Aedes aegypti larvae of some medicinal South American plants. J. Ethnopharmacol., 72: 185$189,2000$. 


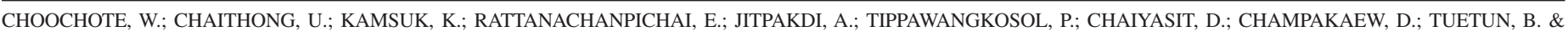
PITASAWAT, B. - Adulticidal activity against Stegomyia aegypti (Diptera: Culicidae) of three Piper spp. Rev. Inst. Med. trop. S. Paulo, 48(1): 33-37, 2006.

5. CORBEL, V.; DUCHON, S.; ZAIM, M. \& HOUGARD, J.M. - Dinotefuran: a potential neonicotinoid insecticide against resistant mosquitoes. J. med. Entomol., 41: 712$717,2004$.

6. JEYABALAN, D.; ARUL, N. \& THANGAMATHI, P. - Studies on effects of Pelargonium citrosa leaf extracts on malarial vector, Anopheles stephensi Liston. Biores. Technol., 89: 185-189, 2003.

7. KHAN, M.F. \& AHMED, S.M. - Toxicity of crude neem leaf extract against housefly Musca domestica L. adults as compared with DDVP, Dichlorvos. Turk. J. Zool., 4: 219-233, 2000.

8. LEE, S.E. -Mosquito larvicidal activity of pipernonaline, a piperidine alkaloid derived from long pepper, Piper longum. J. Amer. Mosq. Control Assoc., 16: 245-247, 2000 .

9. MACKINNON, S.; CHAURET, D.; WANG, M. et al. - Botanicals from the Piperaceae and Meliaceae of the American neotropics: Phytochemistry. In: HEDIN, P.A.; HOLLINGWORTH, R.M.; MASLER, E. P.; MIYAMOTO, J. \& THOMPSON, D.G., ed. Phytochemicals for pest control. Washington, American Chemical Society, 1997. p. 49-57. (ACS Symposium Series 658).

10. MINISTRY OF PUBLIC HEALTH - Annual report 2003. Chiang Mai, Chiang Mai Provincial Public Health Office, 2004.

11. NAIR, M.G. \& BURKE, B.A. - Antimicrobial Piper metabolite and related compounds. J. Agric. Food Chem., 38: 1093-1096, 1990.

12. NUMBA, T. - The encyclopedia of Wakan-Yaku (Traditional Sino-Japanese Medicine) with color pictures. Osaka, Hoikusha, 1993. v. 2.

13. PARK, I.K.; LEE, S.G.; SHIN, S.C. et al. - Larvicidal activity of isobutylamides identified in Piper nigrum fruits against three mosquito species. J. Agric. Food Chem., 50: 1866-1870, 2002.

14. PEREDA-MIRANDA, R.; BERNARD, C.B.; DURST, T. et al. - Methyl 4-hydroxy-3(3'-methyl-2'-butenyl) benzoate, major insecticidal principle from Piper guanacastensis. J. Nat. Prod., 60: 282-284, 1997.

15. PEUNGVICHA, P.; THIRAWARAPAN, S.S.; TEMSIRIRIRKKUL, R. et al. Hypoglycemic effect of the water extract of Piper sarmentosum in rats. J. Ethnopharmacol., 60: 27-32, 1998.

16. PONGBOONROD, S. - Medicinal plants of Thailand. Bangkok, Kasem Banakit, 1976. p. 180.

17. RUKACHAISIRIKUL, T.; SIRIWATTANAKIT, P. SUKCHAROENPHOL, K. et al. Chemical constituents and bioactivity of Piper sarmentosum. J. Ethnopharmacol., 93: 173-176, 2004.

18. REINERT, J.F.; HARBACH, R.E. \& KITCHING I.J. - Phylogeny and classification of Aedini (Diptera: Culicidae), based on morphological characters of all life stages. Zoo., 142: 289-368, 2004.

19. SARALAMP, P.; CHUAKUL, W.; TEMSIRIRIRKKUL R. \& CLAYTON, T. - Medicinal plants in Thailand. Bangkok, Amarin, 1996. v. 1, p. 151.

20. SAWANGJAROEN, N.; SAWANGJAROEN, K. \& POONPANANG, P. - Effects of Piper longum fruit, Piper sarmentosum root and Quercus infectoria nut gall on caecal amoebiasis in mice. J. Ethnopharmacol., 91: 357-360, 2004.
21. SHULTES, R.E. \& RAFFAUF, R.F. - The Healing Forest: medicinal and toxic plants of the Northwest Amazonia. In: SHULTES, R.E. \& RAFFAUF, R.F., ed. Historical, Ethno- \& Economic Botany Series. Portland, Dioscoride Press, 1990. v. 1, p. 362368.

22. SINGH, Y.N. - Kava, an overview. J. Ethnopharmacol., 37: 18-45, 1992.

23. SINGH, Y.N. \& BLUE MENTHAL, M. - Kava, an overview. Herbal Gram., 39: 34-55, 1997.

24. SIVAGNANAME, N. \& KALYANASUNDARAM, M. - Laboratory evaluation of methanolic extract of Atlantia monophylla (Family: Rutaceae) against immature stages of mosquitoes and non-target organisms. Mem. Inst. Oswaldo Cruz., 99: 115-118, 2004.

25. SU, H.C.F. \& HORVAT, R. - Isolation, identification and insecticidal properties of Piper nigrum amides. J. Agric. Food Chem., 29: 115-118, 1981.

26. SUKONTASON, K.L.; BOONCHU, N.; SUKONTASON, K. et al. - Effects of eucalyptol on house fly (Diptera: Muscidae) and blow fly (Diptera: Calliphoridae). Rev. Inst. Med. trop. Sao Paulo., 46: 97-101, 2004.

27. SUKUMAR, K.; PERICH, M.J. \& BOOBA, L.R. - Botanical derivatives in mosquito control: a review. J. Amer. Mosq. Control Assoc., 7: 210-237, 1991.

28. SUNILA, E.S. \& KUTTAN, G. - Immunomodulatory and antitumor activity of Piper longum Linn. and piperine. J. Ethnopharmacol., 90: 339-346, 2004.

29. TAWATSIN, A.; WRATTEN, S.D.; SCOTT, R.R.; THAVARA, U. \& TECHADAMRONGSIN, Y. - Repellency of volatile oils from plants against three mosquito vectors. J. Vector Ecol., 26: 76-82, 2001

30. TSAO, R.; ROMANCHUK, F.E.; PETERSON, C.J. \& COATS, J.R. - Plant growth regulatory effect and insecticidal activity of extracts of tree of Heaven (Ailanthus altissima L.). BMC. Ecol., 2: 1-8, 2002.

31. VIEIRA, R.F. \& SIMON, J.E. - Chemical characterization of basil (Ocimum spp.) found in the markets and used in traditional medicine in Brazil. Econ. Bot., 54: 207-216, 2000 .

32. WHO - Report of the WHO informal consultation on the evaluation and testing of insecticides. CTD/WHOPES/IC/96. 1. Control of Tropical Diseases Division. Geneva, WHO, 1996.

33. WHO - Dengue (online, access in 03/06/2003). Available at http://www.who.int/inf-fs/ en/fact117.html., 2003.

34. WINK, M. - Production and application of phytochemicals from an agricultural perspective. In: VAN BEEK T.A. \& BRETELER H., ed. Phytochemistry and agriculture. Oxford, Clarendon Press, 1993. p 171-213.

35. YANG, Y.C.; LEE, S.G.; LEE, H.K. et al. - A piperidine amide extracted from Piper longum L. fruit shows activity against Aedes aegypti mosquito larvae. J. Agric. Food Chem., 50: 3765-3767, 2002.

Received: 4 February 2005

Accepted: 4 October 2005 